\title{
Effect of varying plant population density on aphid infestation level and yield of faba bean
}

\author{
S.A. El-Dessouki*, G.M. El-Defrawi**, S.M. El-Awadi*, \\ M.K. El-Ansary* and A.A.H. Khalil** \\ * Plant Protection Dept., Fac. Agric. Al-Azhar University. \\ ** Plant Protection Res. Inst., ARC, Minist. Agric., Dokki, Giza-Egypt.
}

\begin{abstract}
Four plant populations: 8, 16, 24 and 32 plants per square meter were tested for their effects on aphid infestation levels and yield potentiality of faba bean (Vicia faba L.) Giza 843 variety, grown under natural infestation in Sids Agricultural Research Station, Beni-Suef Governorate, throughout two consecutive seasons of 2009/10 and 2010/11. Results indicated that a greater number of cowpea aphids infested the lower dense plant populations. Insect population increased with time in all plant populations tested. Dense planting satisfactorily decreased the proportion of plants infested with cowpea aphid by 27.55 and $34.53 \%$ in 2009/10 and 23.10 and $27.26 \%$ during 2010/11 season at plant population of 24 and 32 plants $/ \mathrm{m}^{2}$. There has been negative relation between aphid abundance and plant density per unit area observed. Also, there was a positive response of seed yield with higher plant population densities; 24 and 32 plants $/ \mathrm{m}^{2}$ confirmed in the two successive seasons. The seed yield of faba bean crop cultivated at the rate of 24 and 32 plants $/ \mathrm{m}^{2}$ increased by $(19.02 \%$ and $20.50 \%$ ), and (14.66 and $34.02 \%)$, over the two lower plant population densities 8 and 16 plants $/ \mathrm{m}^{2}$., in the first and second seasons, respectively. The overall results lead to the conclusion that yields of faba bean Giza 843 variety under environment of infestation with cowpea aphid, A. craccivora in middle Egypt region, could be successfully maximized by planting the crop at $24-32$ plants $/ \mathrm{m}^{2}$ plant density (sowing at 2 seeds /hill in double rows or one seed /hill in three rows, $20 \mathrm{~cm}$ hill to hill distance on ridges $60 \mathrm{~cm}$ apart).
\end{abstract}

Keywords: Faba bean, Plant Density, Aphids, Seed Yield.

\section{Introduction}

Cowpea aphid (Aphis craccivora Koch.) is the most serious insect pest affecting the plant growth of faba bean (Vicia faba L.) in the field. Yield losses depend on the time and intensity of aphid infestation (Bishara et al., 1984). This aphid species is the most common species in the Middle Region of Egypt, as well; it can transmit many viruses efficiently (Bos and Makkouk, 1994 and Srivastava et al., 2010).

Crop production practices may enhance or suppress survival, abundance, and severity of damage of faba bean insect pests. These practices can be used to avoid conditions that favor insect pests or activate conditions detrimental to an increase in insect abundance or damage. Therefore, several cultural practices can be applied in faba bean crop to protect it against aphid attacking, mainly through impact of closing spacing by green cultivation. Since this pest survival in different alternate host plants (Megahed, 1979), management of farming system has paramount importance in its cultural control (Risch, 1987; Ferro, 1987 and López-Bellido et al., 2005). Therefore, the present work was carried out to evaluate the effects of different plant population densities on aphid infestation and yield potentiality of the local cultivar Giza 843.

\section{Materials and methods}

A field experiment was conducted at Sids Agricultural Research Station, Beni-Suef Governorate, middle Egypt in 2009/10 and 2010/11 winter growing seasons. The present work aimed to find out the optimum plant population of faba bean (Vicia faba L.) Giza 843 variety grown under natural infestation with cowpea aphids. The crop was sown in the $1^{\text {st }}$ week of November in both tested seasons. Four plant densities $(\mathrm{PD} 1=8, \mathrm{PD} 2=16, \mathrm{PD} 3=24$ and PD4= 32 plants $/ \mathrm{m}^{2}$ by means $33600,67200,100800$, and 134400 plants /fed.) were tested. The experimental plot was $6 \times 7 \mathrm{~m}^{2}$ (1/100 fed.), laid out in a randomized split block design with four replications. Spraying against insect pests or diseases were omitted but the whole experimental area was hand-weeded twice and weeds were kept well controlled. The plots were harvested between 5-10 May in the two seasons. The final harvested seed yield was calculated from a net area of $25 \mathrm{~m}^{2} /$ plot. During the vegetative growth stages, in any sampling date, 10 plants /plot were randomly chosen and replicated 4 times at each field plot of the respective treatments (four plant population densities) were followed. The activity and abundance of cowpea aphid, Aphis craccivora Koch, were weekly recorded starting from the $1^{\text {st }}$ week of December 2009 and 2010 until the end of the season in the $2^{\text {nd }}$ week of April 2010 and 2011. Insects on the upper most two- 
thirds of plants (one central shoot /plant) were checked using the inverse binomial sampling technique (Hafez, 1964). The mean of the 4 replicates was worked out to represent population density. Data were tabulated and statistically analyzed adopting the procedure of Snedecor and Cochran (1980).

\section{Results and discussion}

\section{Aphid in relation to plant population:}

Fluctuations in population density of Aphis craccivora of faba bean plants grown under four plant population densities viz., 8, 16, 24 and 32 plants per square meter were estimated weekly after three weeks from seeding date and continued until the infestation almost disappeared in the field lasting 19 and 18 weeks throughout the first and second seasons, respectively. Obtained data are presented in Table 1. This species was more abundant during $2009 / 10$ than 2010/11 season. Statistical analysis of the data showed that plant population density had significant effects on weekly mean counts of the cowpea aphid existed on faba bean plants, throughout the nineteen and eighteen successive counts $(P=>0.001)$.

During 2009/10 season, faba bean field plots planted at the density of 8 and 16 plants $/ \mathrm{m}^{2}$ confronted higher population density of aphid (614.5 \pm 32.5 and $551.2 \pm 27.7$ individuals /plant shoot), forming one group (GI) with nonsignificant difference. On contrary, field plots planted at the higher rate 24 and 32 plants $/ \mathrm{m}^{2}$, comparatively harbored lower infestations rates of aphids being $(422.4 \pm 22.7$ and $381.5 \pm 21.8$ individuals /plant shoot), and also forming one group (GII) with nonsignificant difference. During the second season 2010/11, the same trend of aphid abundance on faba bean plants existed. Faba bean plots planted at lower plant density per square meter ( 8 and 16 plants $/ \mathrm{m}^{2}$.) exhibited the highest response to cowpea aphid infestations; while those planted at higher population densities 24 and 32 plants $/ \mathrm{m}^{2}$, harbored lower numbers of cowpea aphids. The four means of seasonal aphid counts sustained the faba bean plants being $291.1 \pm 13.5,268.9 \pm 13.1,215.3 \pm 10.5$ and $203.6 \pm 10.1$ insects /plant shoot, for the field plots cultivated at the rate of $8,16,24$ and 32 plants $/ \mathrm{m}^{2}$, respectively. Data further referred; there were highly significant relationships between aphid number and plant densities (E.V. $=96.34$ and $94.39 \%$, in the first and second seasons, respectively). The higher and the lower rates of plant densities were negatively affected by $A$. craccivora population in the two successive seasons 2009/10 and 2010/11 ( $r=-0.9815$ and -0.9716, respectively). The lowest aphid population was obtained when planting took place at higher density 24 and 32 plants $/ \mathrm{m}^{2}$; meanwhile, the lower rate of plant populations 8 and 16 plants $/ \mathrm{m}^{2}$, sustained the higher aphid populations in the two tested seasons (Fig., 1). The negative relation between aphid abundance and plant density per unit area observed is in agreement with the results of Auclair (1989) that related usually higher fecundity and reproductive periods of this aphid species. Interestingly, aphid abundance was strongly correlated with plant population density of the tested cultivar Giza 843 variety. These results agree with the findings of Holt and Wratten, 1986; El-Defrawi et al., 1998 and Asin and Pons, 2001. Salem (1998) found that infestation with $A$. craccivora on broad bean during February was higher on plants cultivated on two sides or alternative on both sides of a row than that on plants sown on one side with nonsignificant difference.

The fore-mentioned results lead to the conclusion that dense planting of faba bean satisfactorily decreases the proportion of plants infested with cowpea aphids by $(27.55 \%$ and $34.53 \%)$ in $2009 / 10$; and $(23.10 \%$ and $27.26 \%$ ), in the second season 2010/11, at the plant population rates of 24 and 32 plants $/ \mathrm{m}^{2}$, and in turn, reduces the subsequent rate of multiplication of aphids and finally the size of the population per unit area, probably because individual plants in dense stands are less nutritious and have a shorter maturation time than those in low stands as anatomized by Way and Heathcote (1966). Furthermore, in such crops of similar high density, plants with narrower spacing between hills had smaller peak numbers of aphids than those with wider spacing (A'Brook, 1977; Helaly et al., 1994 and Muhammed et al., 2006).

\section{Seed Yield Potentiality:}

Seed yield per unit area was increased with increasing plant density with nonsignificant difference between 24 and 32 plants $/ \mathrm{m}^{2}$ in the two tested seasons 2009/10 and 2010/11 as shown in Fig., 2. These findings coordinated with El-Deeb (1982) and Amer (1986) who found no reliable yield increases due to plant densities above 24 plants $/ \mathrm{m}^{2}$. However, Mohamed (1985), observed yield increases due to plant densities between 11 and 47 plants $/ \mathrm{m}^{2}$. This is expected since the maximization of seed yield is depending on the genotype and controlled environments. The number of plants per unit area at harvest followed a pattern similar to that of seed yield. Higher rate of plant populations 24 and 32 per square meter produced $(20.02$ and $21.50 \mathrm{Kg} / 100$ $\mathrm{m}^{2}$.) in 2009/10 season and (40.57 and $35.02 \mathrm{Kg} / 100$ $\mathrm{m}^{2}$ ), in the second season $2010 / 11$, out yielding other plant population densities. 
Table 1. Changes in the population density of A. craccivora on faba bean plants cultivated under four plant population densities during 2009/10 and 2010/2011 seasons, sids, ARS, Beni-Suef governorate, middle Egypt.

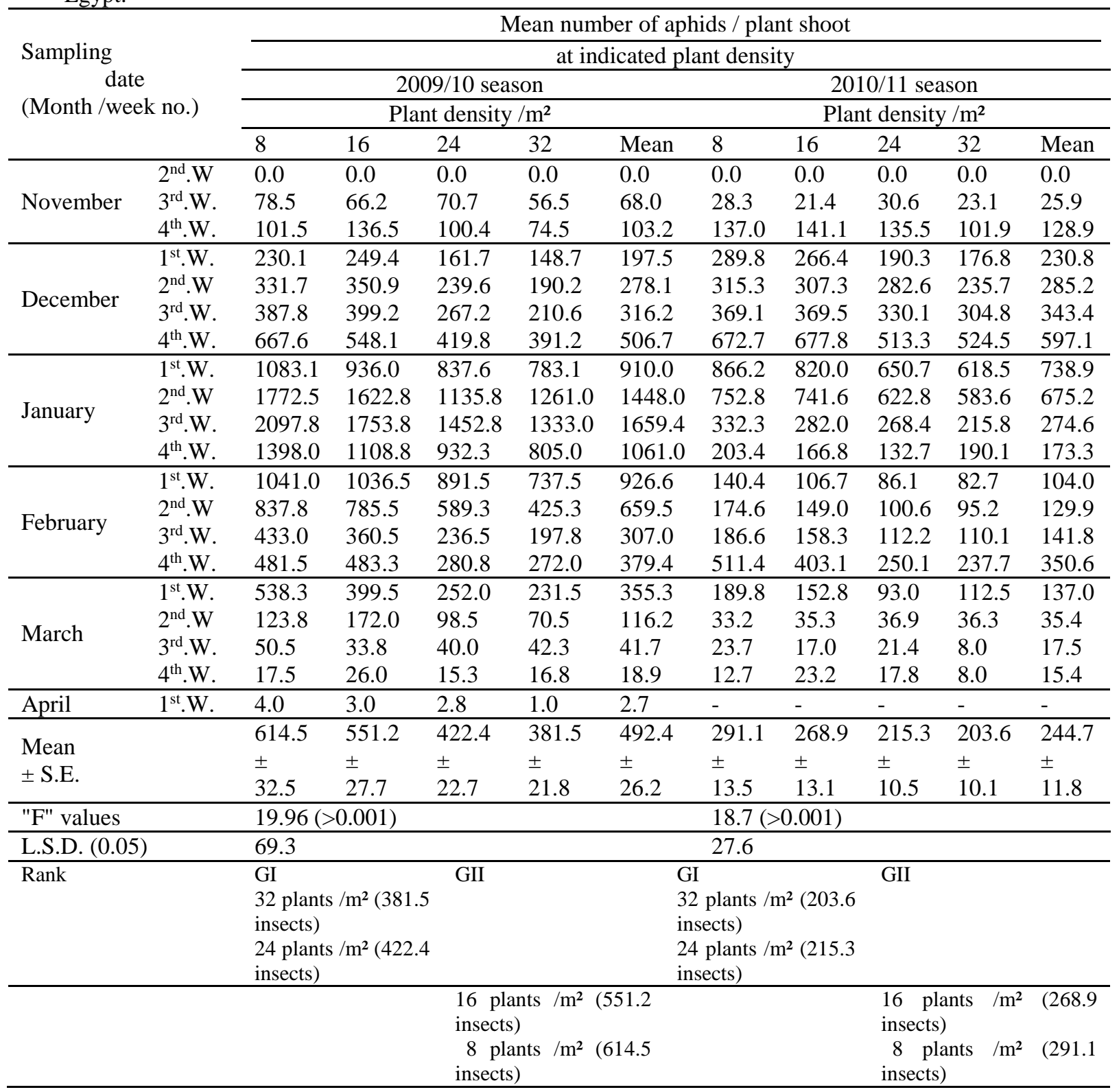




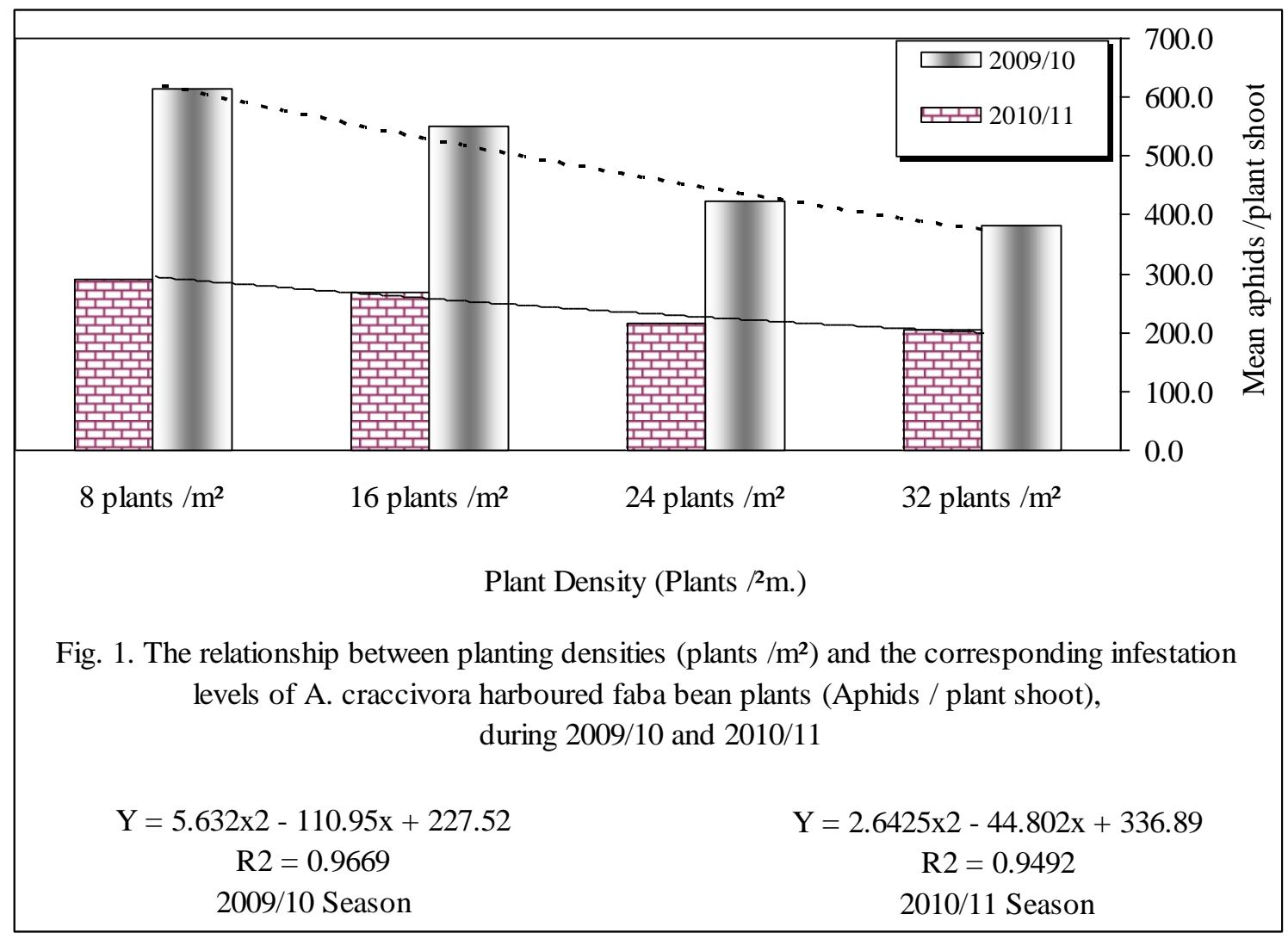

The seed yield of faba bean crop cultivated at the rate of 24 and 32 plants per square meter increased by (19.02\% and $20.50 \%$ ), and (14.66 and $34.02 \%)$, than the two lower plant population densities 8 and 16 plants $/ \mathrm{m}^{2}$, in the first and second seasons, respectively. In general, there has been a constant association between number of plants per unit area and seed yield obtained (Fig. 2). These results indicate the possibility of increasing the productivity of faba bean yield by using a population density between (24 and 32 plants $\left./ \mathrm{m}^{2}\right)$, which are corresponding to 100800 and 134400 plants /fed. (1 fed $=4200 \mathrm{~m}^{2}$ ).

The aforementioned results in Table 1 and illustrated in Fig. 1 and 2 revealed, that the dense canopies (24 and 32 plants $/ \mathrm{m}^{2}$ ) harbored lower levels of aphid abundance and significantly produced higher seed yield than sparse densities due to direct impact of insects on the physiological processes of plants. Infestation may also cause severe disruption of plant tissues or even the death of plants (Forrest et al., 1973; Dantuna and Thomson, 1983 and Tosh, 1998). The relationship between aphid abundance and seed yield of the recommended cultivar Giza 843 variety in the two tested seasons was strong and linear $(\mathrm{r}=-0.9089$ and $-0.8882, P>0.001)$, with explained variance of $82.61 \%$ and $78.89 \%$, in the two tested seasons, respectively. This implying that aphid abundance on plants was dependent upon environmental differences which have impact on seed yield. Accordingly, the change in yield potentiality and corresponding number of aphids on plants in the four plant densities may be used as parameter, it could be predicated as the increase in aphids per plant $(\mathrm{X})$ is usually followed by decrease in yield (Y), expressed as follows: $\mathrm{Y}=(-82.789 \mathrm{X}+$ $\left.699.36, R^{2}=0.9634\right)$ and $\left(-31.589 \mathrm{X}+323.68, \mathrm{R}^{2}=\right.$ $0.9439)$, resulted in the two tested seasons, respectively (Fig., 1). Similar effects of infestation have been recorded in many aphid species. However, different aphid species may have different effects on the same host plant. For example, Aphis fabae causes a reduction in the weight of seeds and the number of seeds per pod in Vicia faba, while Acyrthosiphon pisum may only reduce seed weight (Bouchery, 1977). Similar findings were obtained by Mohamed (1985), who observed yield increases due to plant densities between 11 and 67 plants $/ \mathrm{m}^{2}$. This is expected since the maximization of seed yield is depending on genotype as well the controlled environments. Many authors (Sprent et al., 1977; Abo El-Zahab et al., 1981 and Poulain, 1984) recorded that increases in plant density lead to reductions in branching and pod numbers /plant without much change in either seed size or seeds /pod.

Yield losses in faba bean due to A. craccivora have also been shown to depend on the timing and intensity of colonization (Salem, 1998 and Hossni, 2004). They also pointed out that infested cultivars of faba bean by relatively low aphid numbers (few per plant shoot) showed a simulative effect on plant growth and reduced their susceptibility to aphids. 
Fewer crops stand (lower plant population) harboring higher number of insect pests that could lead to increased damage of crop leaves, stems and yield components. Eventually, crop yield is inversely affected at lower plant populations attracting increased number of insect pests. El-Defrawi, 2009 reported that faba bean seeds and straw yield damages by cowpea aphid increased when plant populations decreased from 33,25 to 11 plants $/ \mathrm{m}^{2}$ in sole cropping close to legume crops such as fenugreek, chickpea and lentil. Plant population density, nevertheless, contributed to the total seed yield of the crop. The present results showed a positive response of seed yield with higher plant population densities, 24 and 32 plants $/ \mathrm{m}^{2}$. These results are in agreement with the findings of El-Deeb, 1982; Mohamed, 1985; Amer, 1986 and Hossni, 2004. Many authors pointed out that physiological changes have been recorded in plants following aphid infestation. Those included reduction in water permeability and the level of carbohydrate reserves (Putritch and Talmon-deI'Armee, 1971 and Christine et al., 2005) and higher and lower levels of growth- inhibiting and growth-promoting substance, respectively, in the radish, Raphanus sativus, after infestation by Myzus. persicae (Hussain et al., 1974). As cowpea aphid, delivers toxic substances by salivary secretions, it is generally assumed that their effect on growth is mainly due to removal of phloem sap from their host plants. Thus, aphid infestation reduces the mass flow of nutrients into the primary growth zone (Mittler and Sylvester, 1961; Pollard, 1973).

The overall results of the present investigation indicate that seed yields of faba bean Giza 843 variety under environment of infestation with cowpea aphid, A. craccivora which commonly common attack plants annually in Beni-Suef Governorate, middle Egypt, could be successfully maximized by means of reducing the reduction caused by insect pest attack to faba beans by planting the crop at 24-32 plants $/ \mathrm{m}^{2}$ plant density (sowing at 2 seeds /hill in double rows or one seed /hill in three rows, $20 \mathrm{~cm}$ hill to hill distance on ridges $60 \mathrm{~cm}$ apart) proved to reduce the cowpea aphids damage.

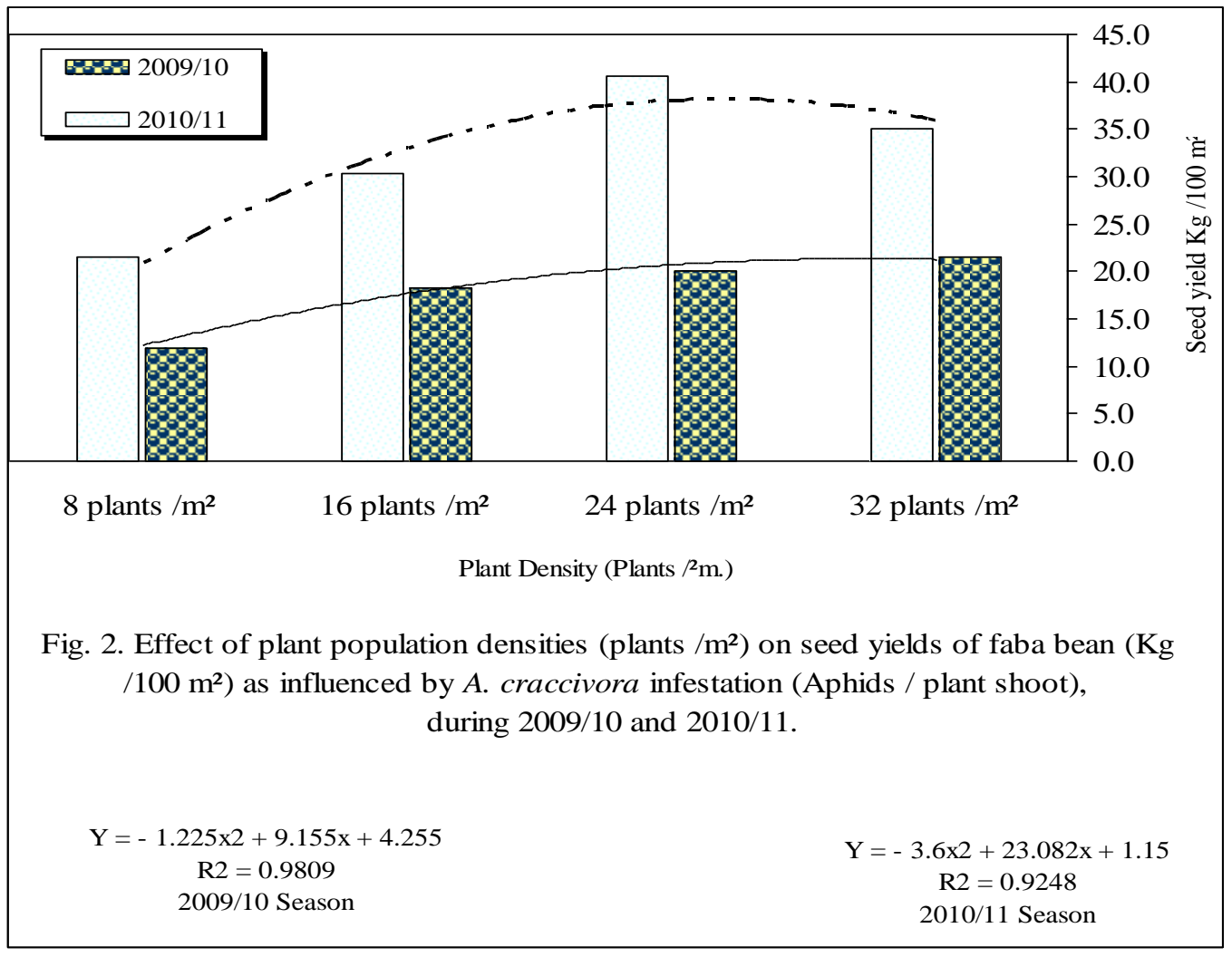

\section{References}

Abo El-Zahab, A.A.; Al-Babawy, A.A. and K. Abd El-Latif (1981). Density studies on faba beans (Vicia faba L.) I. Seed yield and its components. J. Agr. and Crop Sci., 150: 291-302.

A'Brook, J. (1977). The effect of plant spacing on the number of aphids trapped over cocksfoot and kale crops. Ann. Appl. Biol., 74: 279-285.
Amer, M.I.A. (1986). Effect of some agronomic practices on productivity of some broad bean varieties. Ph. D. Thesis, Fac. of Agric. Zagazig Univ., Egypt.

Asin L. and X. Pons (2001). Effect of high temperature on the growth and reproduction of corn aphids (Homoptera: Aphididae) and implications for their population dynamics on the north-eastern Iberian peninsula. Environ. Entomol. 30(6): 1127-1134. 
Auclair, J.L. (1989). Host plant resistance. Aphids, their biology, natural enemies, and control, Vol. C: 225 - 254.Text Book, edited by A. K. Minks and P. Harrewijn. Res. Inst. for Plant Prot., Wagengen, The Netherlands, Elsevier, Amsterdam, Oxford, New York, Tokyo, 1988.

Bishara, S.I.; Fam, E.Z.; Attia, A.A. and M.A. ElHariry (1984). Yield losses of faba bean due to aphid attack. FABIS Newsletter No. 10 : 16-18, Dec. 1994.

Bos, L. and K.M. Makkouk (1994). Insects in relation to virus epidemiology in cool season legumes. pp. 305-332. In F. Muhelbauer and W. Kaiser eds., Expanding the Production and use of Cool Season Legumes. Kluwer Academic Publishers.

Bouchery, Y. (1977). Les pucerons Aphis fabae Scop., et Acyrthosiphon pisum (Harris) (Homopteras : Aphididae) de'pre'dateurs de la fe'verole de printemps (Vicia faba L.) dans le Nord-Est de la France: influence sur le rendement des cultures. Me'chanisme de la de'pre'dation. Annales de Zoologie- Ecologie Animals, 9: 99109.

Christine, G.; Bruno, M.; Wendy, S. and B. JeanLouis Bonnemain (2005). Aphid infestation causes different changes in carbon and nitrogen allocation in alfalfa stems as well as different inhibitions of longitudinal and radial expansion Plant Physiol. 2005 139: 1927-1934.

Dantuna G., and R. Thomson (1983). Whole-crop physiology and yield components. In the faba bean (Vicia faba L.), A Basis for Improvement, pp 143-158. Ed. P.D. Hebblethwaite. London, UK: Butterworths

El-Deeb, B.A.M. (1982). Evaluation of some local and introduced varieties and lines of field bean under different plant densities. M. Sc. Thesis Fac. of Agric. Al-Azhar Univ., Egypt.

El-Defrawi, G.M. (2009). Arthropod pests of coolseason food legumes and their management in Egypt. Egypt. J. Agric. Res., 87 (2): 261-309.

El-Defrawi, G.M.; Mahmoud, S.A. and F.H. Shalaby (1998). Resistance to cowpea aphid in faba bean (Vicia faba L.) Egyptian landraces. Proc. $8^{\text {th }}$. Conf. Agron., Suez Canal Univ., Ismailia, Egypt, 28-29 Nov., 1998: 290-299.

Ferro, D.N. (1987). Insect pest outbreaks in agroecosystems. pp. 195-215. In P. Barbosa and J. C. Schultz (eds.), Insect Outbreaks. Academic Press, New York.

Forrest, J.M.S.; Hussain, A. and A.F.G. Dixon (1973). Growth and wilting of radish seedlings Raphanus sativus infested with the aphid, Myzus persicae. Ann. Appl. Biol., 75: 267-274.

Hafez, M. (1964). Estimation of aphid abundance in the field. Dept. Agrarian Culture, Min. Agric., UAR, pp. 27.
Helaly, M.M.; Hassanein, S.S.M.; Metwaly, E.M.; Desuky, W.M. and H.M. Al-Shannaf (1994). Effect of certain Agricultural practices on the population density of some cotton pests. Zagazig J. Agric. Res., 22 (1): 159-174.

Holt J. and S.D. Wratten (1986). Components of resistance to Aphis fabae in faba bean cultivars. Entomol. exp. appl., 40: 35-40.

Hossni, S.A. (2004). Ecological and biological studies on different aphid species infesting some legume plants in Egypt. M.Sc. Thesis, Fac. Agric. Zagazig Univ., $242 \mathrm{pp}$

Hussain, A.; Forrest J.M.S. and A.F.G. Dixon (1974). Sugar, organic acid, phenolic acid and plant growth regulator content of extracts of honeydew of the aphid, Myzus persicae and its host plant, Raphanus sativus. Annals of Applied Biology, 78: 65-73.

López-Bellido, F.J.; López-Bellido L. and R .J. López-Bellido (2005). Competition, growth and yield of faba bean (Vicia faba L.). European J. Agron., 23 (4): 359-378.

Megahed, M.M.; El-Nagar, S. and A.M. Amin (1979). Seasonal abundance of certain aphid species on wild plants in Giza-Egypt. Bull. Soc. Ent. Egypte, 62: 279-284.

Mittler T.E. and E.S. Sylvester (1961). A comparison of the injury of alfalfa by the aphids Therioaphis maculata and Macrosiphum pisi. J. Econ Entomol., 54: 615-622.

Mohamed, A.K. (1985). Effect of sowing date, ridge direction, plant orientation, and population on faba bean grain yield. FABIS Newsletter, August 1985, 12: 11-12.

Muhammed, J.A.; Muhammed, D.G.; Mansoor, M.; Khuran, Z. and H. Faisal (2006). Impact of plant spacing and abiotic factors on population dynamics of sucking insect pests of cotton. Pakistan J. Biological Sci., 9(7):1364-1369.

Pollard, D.G. (1973). Plant penetration by aphid feeding aphids (Hemiptera, Aphidoidea): A Review. Bull Entomol Res 62: 631-714

Poulain, D. (1984). Influence of density on the growth and development of winter field bean (Vicia faba ). Pages 151-167 in Vicia faba; Agronomy, physiology and breeding (Hebblethwaite, P. D., Dawkins, T. C. K., Health, M. C. and Lockwood, G., Eds).

Putritch, G.S. and M. Talmon-de I' Armee (1971). Effect of balsam wooly aphid, Adelges piceae (Ratz.) infestation on the food reserves of the grand fir, Abies grandis. Canadian Journal of Botany, 49: 1219-1223.

Risch, S.J. (1987). Agricultural ecology and insect outbreaks. pp. 217-238. in P. Barbosa and J. C. Schultz (eds.), Insect Outbreaks. Academic Press, New York.

Salem, A. and El-Deen A. (1998). Ecological studies on certain insects associated with broad 
bean (Vicia faba) in Minia Region, Egypt. M. Sc. Thesis, Fac. Agric. Minia Univ., 145 pp.

Snedecor, G.W. and W.G. Cochran (1980). Statistical methods. $7^{\text {th }}$. Edn. Ames. Iowa: Iowa State University Press. 507 pp.

Sprent, J.I.; Bradford A.M. and C. Norton (1977). Seasonal growth patterns in field beans (Vicia faba) as affected by population density, shading and its relationship with soil moisture. Journal of Agricultural Science, Cambridge 88: 293-301.
Srivastava, M.; Gupta U.P. and A. Sinha (2010). Viral diseases of leguminous crops. J. Sci. Res., 54: 135-152.

Tosh, C.R. (1998). Host Plant Specialisation in The Black Bean Aphid, Aphis fabae. Ph. D. Thesis, University of York, U.K.

Way, M.J. and G.D. Heathcote (1966). Interactions of crop density of field beans, abundance of Aphis fabae (Scop.), virus incidence and aphid control by chemicals. Ann. Appl. Biol., 57: 409 423. 


\section{تأثثر أختلاف الكثافة النباتية على مستوى الإصابة بحشرات المن وإنتاجية الفول البلاي}

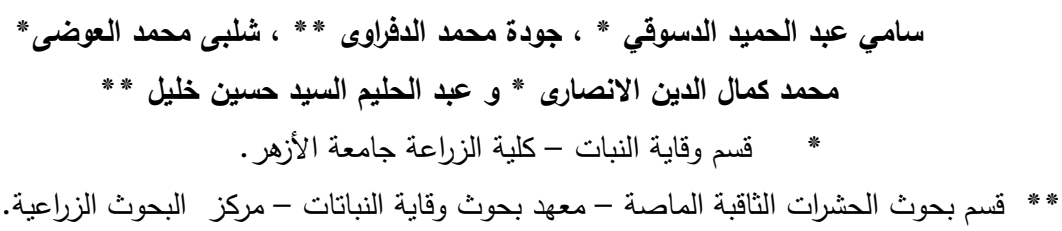

تعتبر الكثافة النباتية في وحدة الدساحة فى الفول البلاي من أهم التوصيات الفنية المرتبطة بتعظيم الإنتاج لدى المزارعين، وحيث لا تنوافر

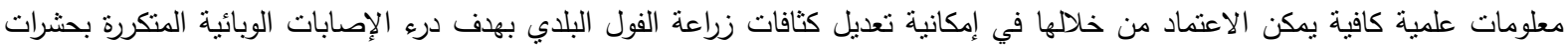

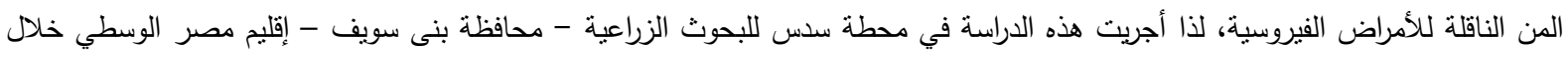

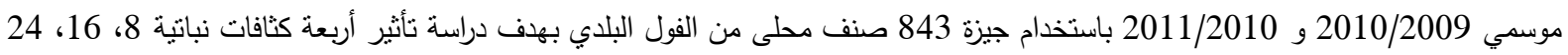
و 32 نبات في المنر المربع أي ( 33600، 67200، اللوبيا Aphis craccivora ومدى قدرته على إنتاج محصول البذرة نحت هذه الظروف وكذا أيجاد أنسب كثافة نباتية تعمل على خفض الإن الإصابة إلى أدنى حد وتحقق إنتاجية عالية دون استخدام مبيدات حشرية أو كيماويات ملوثة للبيئة.

1. أظهرت الننائج وجود اختلاف معنوي لتعداد حشرة من اللوبيا التي أصابت نباتات الفول البلاي صنف جيزة 843 حيث تميزت نباتات الفول ذات الكثافات العالية بنقص شدة إصابتها بهذه الحشرة.

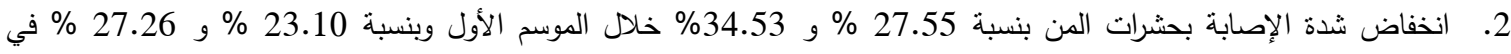

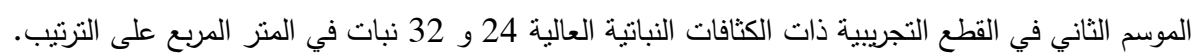

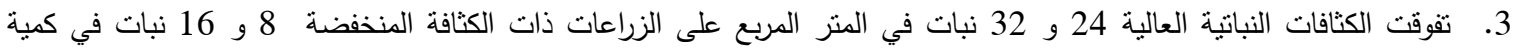

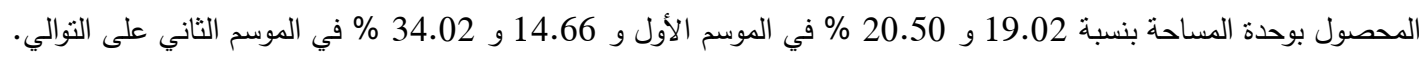
وبناء على النتائج المنحصل عليها يمكن التوصية بزراعة محصول الفول البلدي في منطقة مصر الوسطي بكثافة نباتية تتزاوح بين 100800 و 134400 نبات في الفدان أى بمعدل 24-32 نبات في المنز المربع لنقليل الإصابة بحشرات المن في نلك المنطقة ولضمان إنتاج وفير من البذور بوحدة المساحة تحت هذه الظروف. 